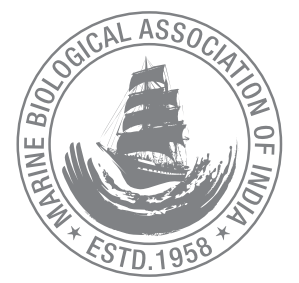

\title{
Isolation, identification and culture of the marine rotifer Colurella adriatica Ehrenberg, 1831 (Family: Lepadellidae) from Andaman \& Nicobar Islands: A promising live feed for larval rearing of high value shellfishes and finfishes
}

\author{
K. Madhu*, Rema Madhu, M. P. Mohandas and M. T. Vijayan \\ ICAR-Central Marine Fisheries Research Institute, Kochi- 682 018, Kerala, India. \\ Correspondence e-mail: kmadhu30@rediffmail.com
}

Received: 17 Nov 2015, Accepted: 02 Apr 2016, Published: 30 Jun 2016

Original Article

\begin{abstract}
An extremely small rotifer was isolated from the micro zooplankton samples collected during February, 2014 from Havelock islands of Andaman and Nicobar Islands. The species was identified as Colurella adriatica Ehrenberg, 1831 (Family: Lapadellidae). Its lorica length under culture period ranged from 47.530 to $98.868 \mu \mathrm{m}$ and width from 34.308 to $56.277 \mu \mathrm{m}$. The size of the eggs, neonates and adults are also documented. Comparison of size of $C$. adriatica with Brachionus plicatilis ( $\mathrm{L}$ type) and B. rotundiformis (S and SS type) revealed that C. adriatica is smaller in length and width than the SS-type rotifer which is currently used as a first feed in marine tropical fish larval rearing. However, the larvae of many marine food fishes including groupers and high value marine ornamental fishes are unable to consume the SS-type rotifers as a first feed due to their extremely small mouth gape. The culture of $C$. adriatica was carried out using Nannochloropsis oculata Diet-I), N. oculata and yeast $(0.01 \mathrm{~g} /$ litre) (Diet-II), Yeast $(0.01 \mathrm{~g} /$ litre) alone (Diet-III). Average population density of $C$. adriatica with these diets reached a maximum of 1000 nos. of individuals $/ \mathrm{ml}$ on 10th day of culture on feeding with Diet-l; 950 nos. /ml on 14th day (Diet-II) and 650 nos. / $\mathrm{ml}$ on 15th day of culture (Diet-III). Diet I \& II and Diet II \&III did not show any significant difference $(P>0.05)$ whereas, Diet I and III showed significant difference $(P<0.01)$. Preliminary studies of C. adriatica as a feed to the larvae of Stenopus hispidus, Lysmata amboinensis and Pomacentrus caeruleus showed better survival than larvae fed with $B$. routundiformis during first phase of larval rearing. The
\end{abstract}

study proved that $C$. adriatica can be used as a promising starter live feed for the larval rearing of marine fishes. This is the first record of C. adriatica from Andaman and Nicobar Islands and the sequences were submitted to GenBank with the accession no KX387633.

Keywords: C. adriatica, rotifer, live feed, culture, population density.

\section{Introduction}

Micro live feeds play a pivotal role in the larval rearing and seed production of marine finfishes and shellfishes as the larvae depend on live prey at their first feeding (Tocher et al., 1997). As the live food organisms are able to swim in the water column and are constantly available to the larvae rather than formulated diets which congregate or sink to the bottom of tanks, the dependence on live feed organisms is increasing day by day. Moreover, the jerking movement of live feed in the water column also help to stimulate feeding response in larvae. The newly hatched larvae are of two types precocial and altricial. Most of the marine fish larvae are altricial type. 
Hence a major impediment in larval rearing is the first feeding stage, when the larvae shift from endogenous yolk reserves to exogenous feeding (Turingan et al., 2005). Most of the hatcheries commonly use species of rotifer Brachionus plicatilis (L type), B. rotundiformis (S and SS Type) and brine shrimp (Artemia sp.) as live feed organisms due to their small size, fast multiplication rate and ease in culture methods (Dhert, 1996). However, larvae of many of the marine food fishes including groupers and high value marine ornamental fishes are unable to consume these live foods as their first feed due to their extremely small mouth gape. It is also established that prey capture success and percentage of successful feeding strikes is low at first feeding by marine fish larvae (Hunter, 1981) but rises rapidly during early development (Houde and Schekter, 1980). At this stage provision of suitable size and nutritionally adequate enriched live feed in high density is one of the important factors for their survival as the larvae will be able to accept only small sized prey organism due to the small mouth gape, and if they do not encounter and successfully capture food before depleting their energy reserves, the larvae may starve and it will eventually leads to mortality. As the mouth gape of most of the fish larvae is between 50- 120 $\mu \mathrm{m}$, the larvae need to be fed with live feeds measuring less than their mouth gape for active feeding, indicating that size of live diet is an important prerequisite in larval nutrition.

The species belonging to the genus Colurella are extremely smaller rotifers in the order Ploima in which Brachionus species is also present. Being a filter feeder, its nutritional quality can also be enhanced with proper enrichment. Occurrence of Colurella sp. are reported from wide range of habitat ranging from freshwater to brackishwater (De Smet, 1994), marine environment (De Smet, 2006); temperate and tropical regions (De Ridder and Segers, 1997; Baribwegure and Segers, 2001; Leszek and Ellison, 2003). The occurrence of Colurella sp. from the backwaters of the Delhi segment of the Yamuna River was reported by Arora and Mehra (2003).

The success of captive production of marine fishes depends on the ability to produce large numbers of good quality larvae that successfully metamorphose to juveniles (Holt, 2003). Eventhough a large number of marine species undergo gonadal maturation and spawn in captivity, prey capture success in the first stage of feeding and subsequent larval developments and metamorphosis still remains as a critical bottleneck in their production (Holt, 2003) due to the non availability of suitable sized and nutritionally adequate live food organisms. As the species belonging to the genus Colurella are much smaller in size than $B$. plicatilis and $B$. rotundiformis, its isolation and development of culture techniques may be useful for the larval rearing of marine fish species for which the currently used live prey organisms are too large. Hence the present study was undertaken to isolate smaller species of rotifer from marine environments from India and to investigate the feasibility of developing stock and mass cultures for evaluating its suitability as first feed in larviculture.

\section{Material and methods}

Micro zooplankton samples were collected by towing plankton nets (20 and $50 \mu \mathrm{m}$ ) during February, 2014 from the littoral and sub littoral areas of coral reef ecosystem of Havelock island of Andamans and Nicobar islands where an assemblage of early juvenile stages of different varieties of marine ornamental fishes were noticed. In the laboratory, the zooplanktons were sorted in live condition using zooplankton sorter of different mesh size, and observed under trinocular microscope. The sorted species were then transferred to $100 \mathrm{ml}$ test tubes containing $50 \mathrm{ml}$ sterilized seawater having $34 \mathrm{ppt}$, and fed with $5 \mathrm{ml}$ of microalgae Chaetoceros calcitrans, Nannochloropsis oculata and Isochrysis galbana and yeast in separate test tubes. The test tube racks were placed in front of light source at 1000 to 1500 lux for 24 hours photoperiod under room temperature $\left(28^{\circ} \mathrm{C}\right)$. Every three days, the samples were observed for a period 15 days with addition of feed and then the culture was further purified by transferring to new culture media. This method of isolation was continued until a pure stock of organism was obtained. Once a pure stock was obtained, the culture was carried out in $250 \mathrm{ml}$ conical flask for stock culture maintenance using $N$. oculata as feed. The species were identified using standard identification characters (Hauer, 1924; Sorenson and Kristensen, 2000; Jersabek and Leitne, 2013) and the different shapes of occurrence were photographed under Trinocular microscope (Leica DMLB-2 attached with camera $450 \mathrm{C}$ ) at $20 \mathrm{x}$ and $100 \mathrm{x}$ magnification and the measurements viz., length and width of lorica and eggs, and length of foot and toes from 100 live specimens were documented using software LAS and its average were taken. The size of $C$. adriatica was also compared with other rotifer species B. plicatilis (L-type), B. rotundiformis (S and SS type) available in the marine hatchery after measuring 100 specimen each. DNA extraction was carried out using a standard phenol/chloroform extraction protocol. A 650bp region of the Cytochrome C oxidase 1 (CO1) was amplified using universal primer (Folmer et al., 1994) in Colurella adriatica collected from Indian waters. Purification of the PCR products was carried out using Qiagen PCR purification kit and sequencing was carried out with BigDye Terminator Sequencing Ready Reaction v3.0 kit (Applied Biosystems) using the primers.

Microalga N. oculata was grown in 15 litre buckets as batch cultures at 20 to $22^{\circ} \mathrm{C}$ under continuous photoperiod of 
1500 to 2500 lux light intensity in the marine hatchery. The influence of three feeds $N$. oculata $\left(10 \times 10^{4}\right.$ to $20 \times 10^{4}$ cells/ ml) (Diet-l), $N$. oculata $\left(5 \times 10^{4}\right.$ to $10 \times 10^{4}$ cells $\left./ \mathrm{ml}\right)+$ Yeast $(0.01 \mathrm{~g} / \mathrm{l})($ Diet-II), and yeast alone $(0.01 \mathrm{~g} / \mathrm{I})($ Diet-III), on its multiplication was carried out in 15 litre cylindrical perspex container with lid to avoid evaporation, and three replicates were maintained. Each container was filled with 10 litres of respective feed, and stocked with 5 Nos. of rotifers $/ \mathrm{ml}$. All the containers were kept under $28^{\circ} \mathrm{C}$ temperatures, $34 \mathrm{ppt}$ salinity, 1000 to 1500 lux light intensity at $24 \mathrm{~h}$ photoperiod with continuous moderate aeration to provide dissolved oxygen level at 3.2 to $3.5 \mathrm{ml} / \mathrm{l}$. The total duration of culture experiment was 17 days. Every day $5 \mathrm{ml}$ of samples from each culture vessels were randomly taken to determine the population density. Before counting, one drop of neutral buffered formalin was applied through the side of cover slip of rotifer counting chamber to anaesthetise the organism. The total number of rotifers in each $\mathrm{ml}$ were calculated and expressed as average of three replicate in each culture container and the number of rotifers were expressed as average number of individuals $/ \mathrm{ml}$. The density of algae in each culture container were determined with a haemocytometer, and adjusted every 3 days during the culture experiment. Data was analysed using ANOVA to determine the effect of various feed on multiplication of C. adriatica. A probability of 0.01 and 0.05 was utilized to account for the statistical difference between the means.

\section{Feeding Trial}

The larvae of blue Caerulean damselfish Pomacentrus caeruleus, marine ornamental banded coral shrimp Stenopus hispidus and scarlet cleaner shrimp Lysmata amboinensis were fed with C. adriatica at 5 to $10 \mathrm{nos} / \mathrm{ml}$ up to 10 days of post hatch and compared with the survival obtained in the larvae fed with $B$. rotundiformis (control) up to 10 days of post hatch. Larval rearing of $P$. caeruleus was carried out in 500 I FRP tanks using micro algae I. galbana, N. oculata and Chlorella salina at 1:2: 2 proportion at cell density $5 \times 10^{5}$ cells/ $\mathrm{ml}$ whereas larval rearing of $S$. hispidus and L. amboinensis was carried out in $500 \mathrm{I}$ black coloured cylndroconical tank using microalgae N. oculata, I. galbana, and C. gracilis at 1:2: 2 proportion at cell density $5 \times 10^{5}$ cells $/ \mathrm{ml}$. Each tank was stocked with 100 nos of larvae. Three replicates were maintained for each treatment. On $10^{\text {th }}$ day of rearing, the larvae survived in each thank were accounted to record the survival.

\section{Results and discussion \\ Identification characteristics}

The species was identified as $C$. adriatica belonging to the Phylum: Rotifera, Class Eurotatoria, Order: Ploima, Family:
Lapadellidae. The different shapes of its occurrence are presented in the line drawings (Fig.1 A-D). The species was identified based on the morphological features as suggested by Hauer (1924); Sorenson and Kristensen (2000); Jersabek and Leitne (2013) and the following characteristics were recorded after observing live

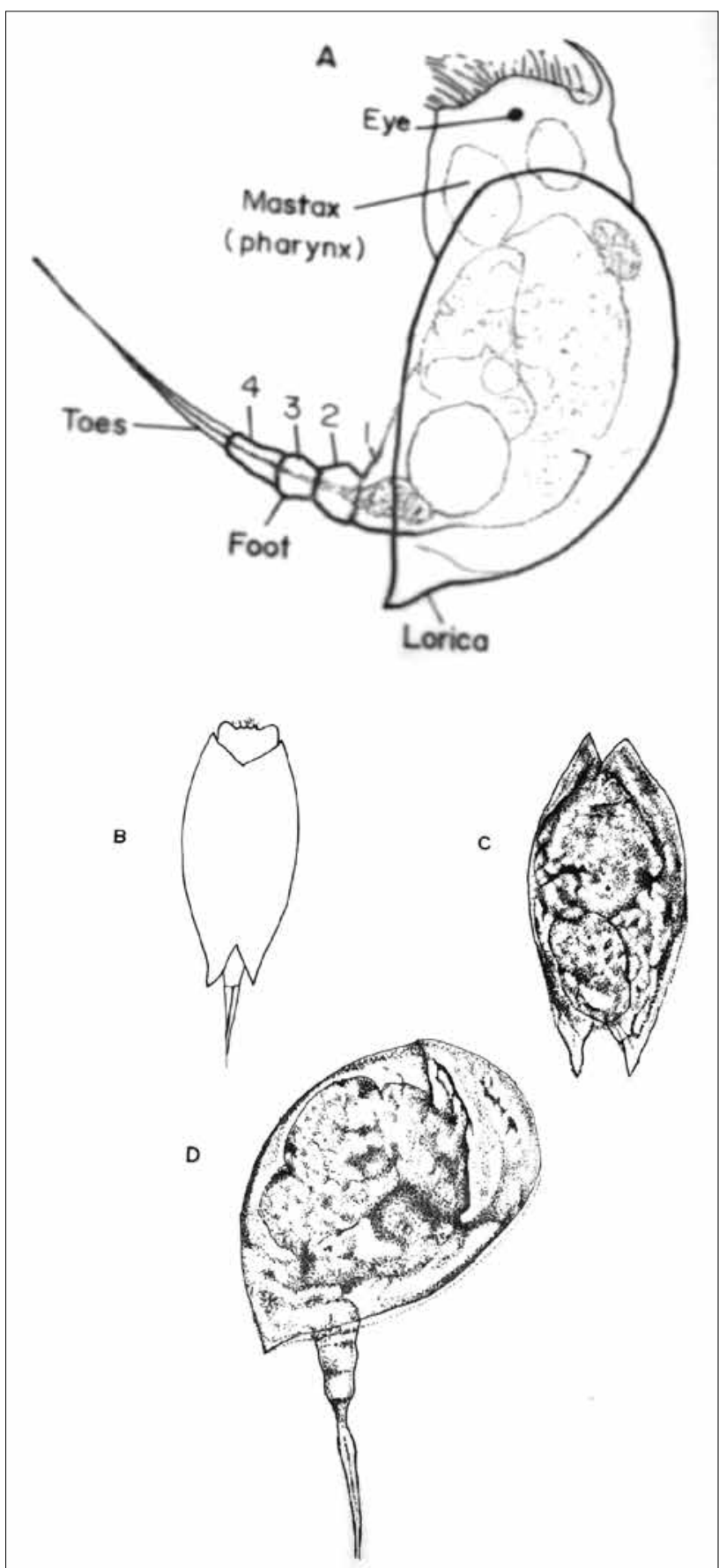

Fig. 1. Line drawing of C.adriatica: A: Adult female showing segmented foot with long toes, eyes and internal organs (Lateral view); B: Dorsal view, C : Mussel shaped side view; D. Semi-circular shield dorsal to the corona retracted completely within lorica 
specimens. Lorica is very variable in size and shape with characteristic divergence of posterior margin which has a pointed and acute shape (Fig. 2A). Lorica composed of two lateral plates, strongly compressed laterally and it open along anterior, ventral and posterior margins. So it appears mussel-shaped in side view (Fig. 2B). Frontal head hood present and the head carries a small, retractable, semicircular shield dorsal to the corona which is retractable completely within lorica (Fig. 2C). The foot consists of four segments and two slender toes which are longer than the length of foot (Fig. 2C). There are two lateral eyes which are red in colour and can be distinguished easily (Fig. 2D). Sorenson and Kristensen (2000) also reported that the species in the genus Colurella are solely recognized by lorica characteristics and the trophi plays no taxonomical role in systematic studies. Pejler (1962) reported a transition morph between $C$. adriatica and C. colurus. Different ecotypes have been described in relation to the size and shape of the lorica, as well as length of the foot. Hauer (1924) reported that both species increased their size with salinity. C. adriatica is often confused with C. colurus. However, C. colurus is relatively smaller than C. adriatica, and it can be distinguished by the morphology of the posterior margin of the lorica, which is rounded.

Though C. adriatica is reported as euryhaline and eurytopic species occurring in current water in the littoral zone among macrophytes, and are considered cosmopolitan (De Ridder and Segers, 1997), it was also recorded from freshwater, brackishwater bodies (De Smet, 1994), temperate, tropical regions (De Ridder and Segers, 1997; Baribwegure and Segers, 2001; Leszek and Ellison, 2003), and from the marine littoral environment of Reunion I $\left(21^{\circ} \mathrm{S}, 55.30^{\circ} \mathrm{E}\right)$ which is one of the Mascarene island lying in the Indian ocean, $800 \mathrm{~km}$ east of Madagascar (De Smet, 2006). The comparison of the trophi of marine specimens from Mascarene island of the Indian ocean with that of freshwater specimens revealed no significant differences
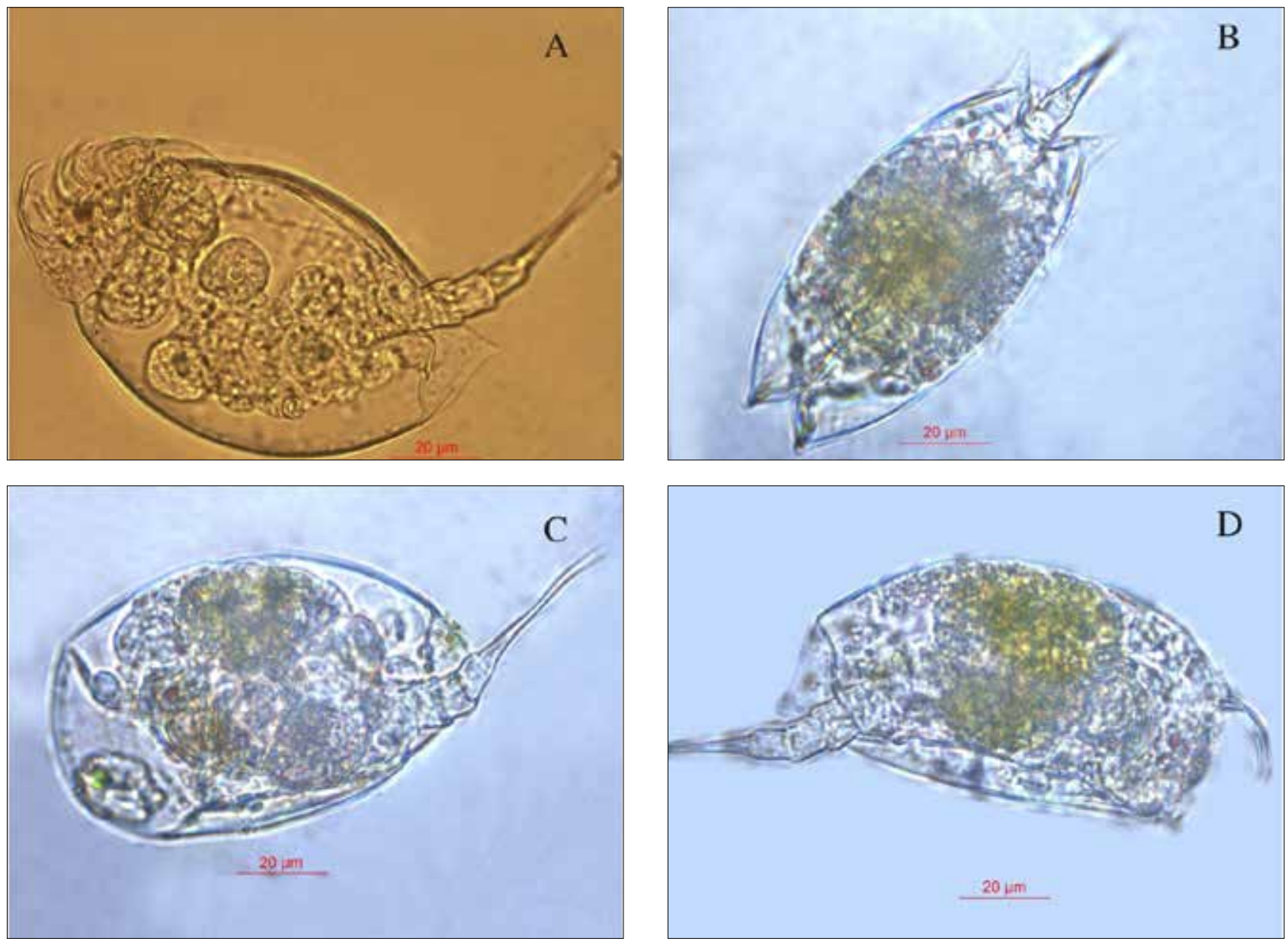

Fig. 2. Microscopic view of live C. adriatica showing morphological characteristics (Magnification: 100x): 2A. Adult female (Lateral view); 2B. Musselshaped side view showing two lateral plates; 2 C. Semi-circular shield dorsal to the corona retracted completely within lorica, showing four segmented foot and two long slender toes; 2D. Lateral view of adult C. adriatica showing red eyes 
(De Smet, 2006) indicating that it can tolerate wide range of salinity fluctuation, and habitats or ecological conditions as reported by De Ridder and Segers (1997). Though occurrence of Colurella sp. from the backwaters of the Delhi segment of the Yamuna river was reported by Arora and Mehra (2003), and annotated a checklist of 42 Indian species of Lepadellidae from northeast India (Shrama and Sharma, 2015), the present study is the first report of occurrence of $C$. adriatica from marine environment, and its isolation and culture in India. The partial sequence of Colurella sp. CO1 was deposited in GenBank with the accession no: KX387633.

\section{Measurements of $C$. adriatica under captive conditions}

The lorica length of the isolated species under culture period ranged from 47.530 to $98.868 \mu \mathrm{m}$ and its width ranged from 34.308 to $56.277 \mu \mathrm{m}$. The size of the eggs ranged from 53.821 to $62.432 \mu \mathrm{m}$ length and 37.543 to $44.176 \mu \mathrm{m}$ width. The lorica length of the neonates ranged from 47.530 to 50.004 $\mu \mathrm{m}$ and their width ranged from 34.308 to $36.702 \mu \mathrm{m}$ (Fig. 3). Size of the adults usually ranged from 70.454 to 98.868 $\mu \mathrm{m}$ lorica length and 54.243 to $56.277 \mu \mathrm{m}$ lorica width. The length of foot ranged from 25 to $30 \mu \mathrm{m}$ and the two toes present were slender, long and separated which measured 30 to $40 \mu \mathrm{m}$ (Fig. 4).

\section{Comparison of size of $C$. adriatica with common rotifers}

In aquaculture, the most widely used species of rotifer are $B$. plicatilis (L-type) and B. rotundiformis (S-type and SS-type), and the results of comparison of their lorica length with that of $C$. adriatica are given in Table 1. The observation revealed that $C$. adriatica the Super Minuscule Rotifer (SMR) is smaller than the super small $B$. rotundifromis. The microscopic photographs of these species documented at 20x magnification are presented in Fig. 5 A-D. The efficacy of SS type rotifer which is presently used as the first feed is questioned as many of the high value fishes are unable to consume this rotifer due to the extremely small mouth gape of larvae (Holt, 2003). The lorica length and width of the common species $B$. plicatilis, $B$. rotundiformis ( $S$ and SS type) used in the present study are also in agreement with data recorded in various studies (Lim,1993; Dhert,
1996; Molly Varghese, 2003). Various studies also pointed out that variation in size and growth can be observed due to geographical location (Hagiwara et al., 1995; Rimper et al., 2008), prevailing culture conditions like temperature, salinity, feed type, feed concentration, etc. (Snell and Carrillo, 1984; Somamihardja and Bart, 2008). Knuckey et

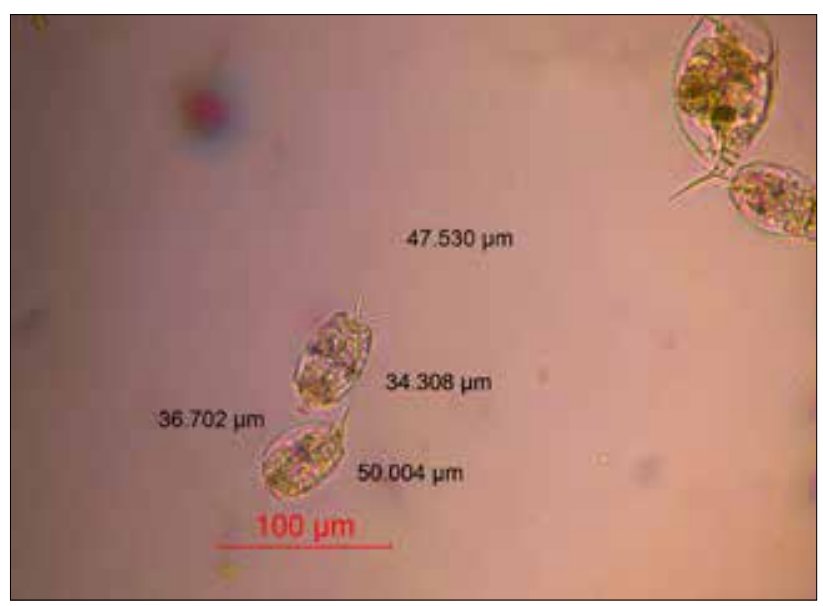

Fig. 3. Microscopic view of neonates of C. adriatica (Magnification 20x).

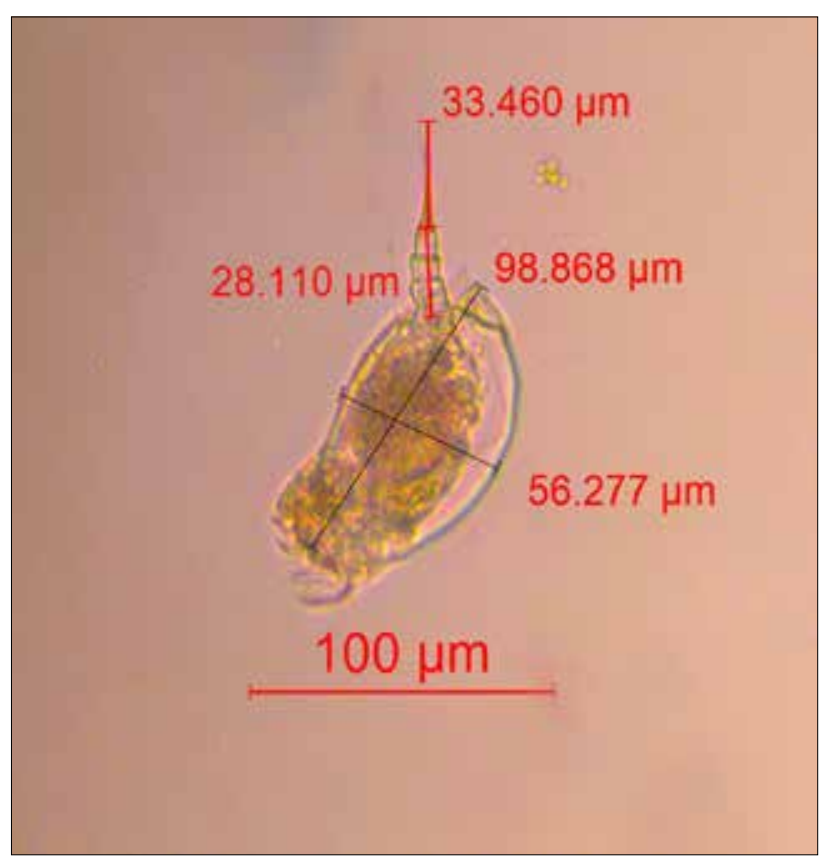

Fig. 4. Measurements of $C$. adriatica showing shorter foot and long slender toes (Magnification 20x).

Table 1. Comparison between Brachionus species and Colurella adriatica in terms of size

\begin{tabular}{lll}
\hline Rotifer species & Lorica length $(\mu \mathrm{m})$ & Lorica width $(\mu \mathrm{m})$. \\
\hline C. adriatica & $47.530-98.868$ & $34.308-56.277$ \\
\hline B. plicatilis (L type) & $130-340$ & $116-146$ \\
\hline B. rotundiformis (S type) & $100-210$ & $98-121$ \\
\hline B. rotundiformis (SS type) & $58-120$ & $58-100$ \\
\hline
\end{tabular}



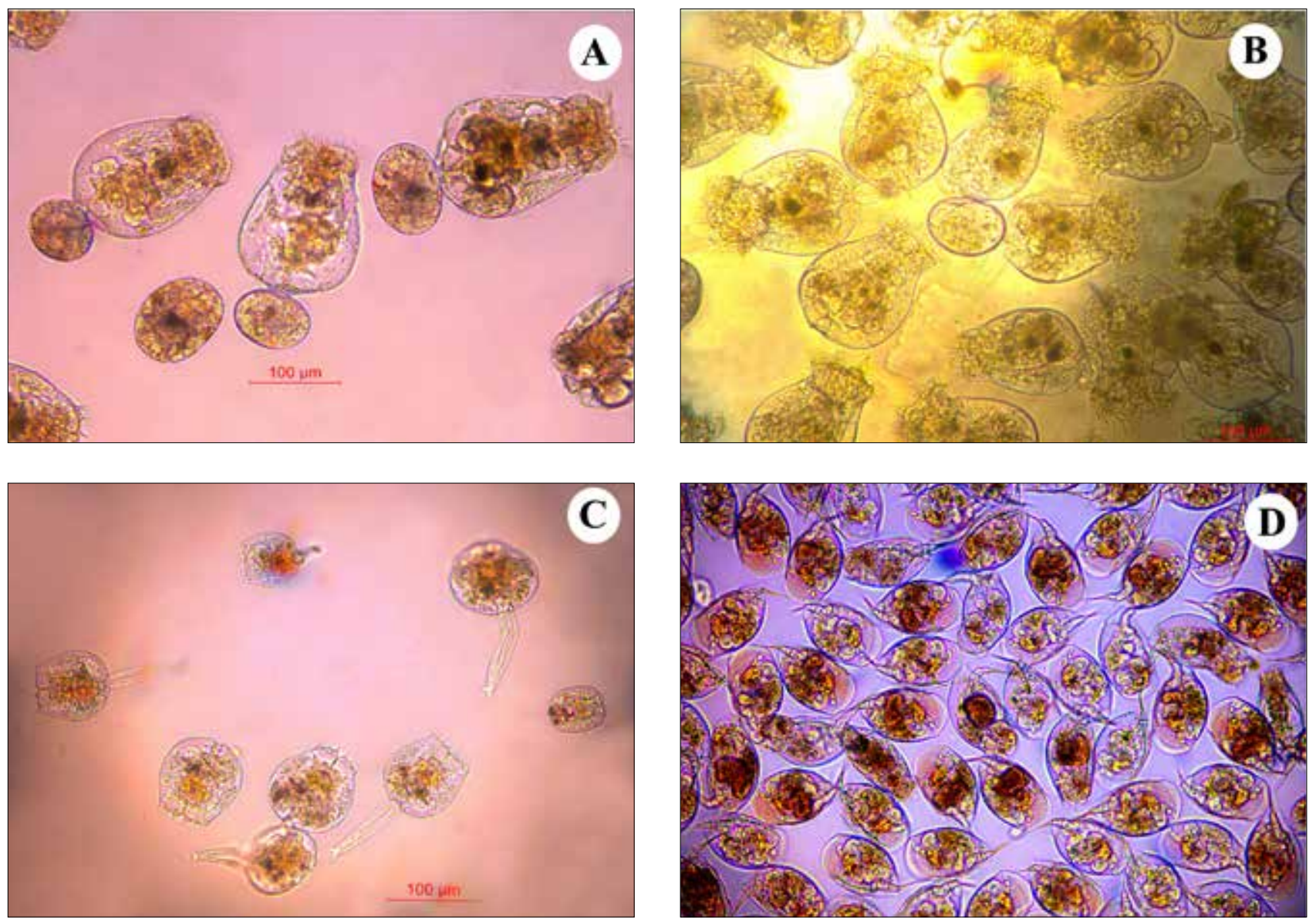

Fig. 5. Comparison of size of different Rotifers (Magnification 20x): 5A. Brachionus plicatilis (L-type), 5B. Brachionus rotundiformis (S-type), 5C. Brachionus rotundiformis (SS Type), 5D. Colurella adriatica

al. (2004) stated that particle size of diet can also influence the degree of morphological plasticity in size.

\section{Population density in the culture experiments}

The culture experiments showed that $C$. adriatica can be multiplied under laboratory condition providing optimum conditions and suitable feed. The population density of rotifer during culture experiments are presented in Fig. 6 . The determination of number of rotifers present in the culture vessels during the 17 days of culture period showed that the treatment fed with $N$. oculata (Diet-I) had attained a population density of 1000 nos. of individuals $/ \mathrm{ml}$ on $10^{\text {th }}$ day of culture. In the treatment fed with $N$. oculata and Yeast (Diet-II) a peak population density of 950 nos. of individuals $/ \mathrm{ml}$ was noticed on $14^{\text {th }}$ day and the culture fed with yeast alone (Diet-III) had reached peak density on $15^{\text {th }}$ day of culture with 650 nos. of individuals $/ \mathrm{ml}$. A hike in the number of individual $\mathrm{s} / \mathrm{ml}$ was noticed from the $6^{\text {th }}$ day of culture onwards. Comparison of population density of rotifer in different diets revealed that between Diet I \&II and Diet II \&III did not show any significant difference
$(P>0.05)$. However, Diet I and III showed significant difference $(P<0.01)$. The study revealed that for mass multiplication of $C$. adriatica, the microalga $N$. oculata can be effectively used as feed. However after attaining peak, unless the culture is harvested or replaced with new algae, the culture showed a collapse. In general, the life span of rotifers has been estimated to be between 3.4 to 4.4 days at $25^{\circ} \mathrm{C}$. Generally, the neonates become adult after 0.5 to 1.5 days and females thereafter start to lay eggs approximately every four hours. It is believed that females can produce ten generations of offspring before they eventually die (Dhert, 1996). The multiplication rate of C. adriatica is reported as $0.765 \pm 0.017$ offspring/ female/day), whereas it was 0.23-1.15 offspring/female/ day, in B. plicatilis and 0.54-1.37 offspring/female/day in $B$. rotundiformis (Dhert, 1996; Stottrup, and Mc Evoy, 2003). The present study also revealed that partial harvesting from $10^{\text {th }}$ day of culture and with replacement of harvested volume with fresh algae can sustain the culture for a period of 17 days. The harvested biomass of $C$. adriatica was yellowish orange in colour. 


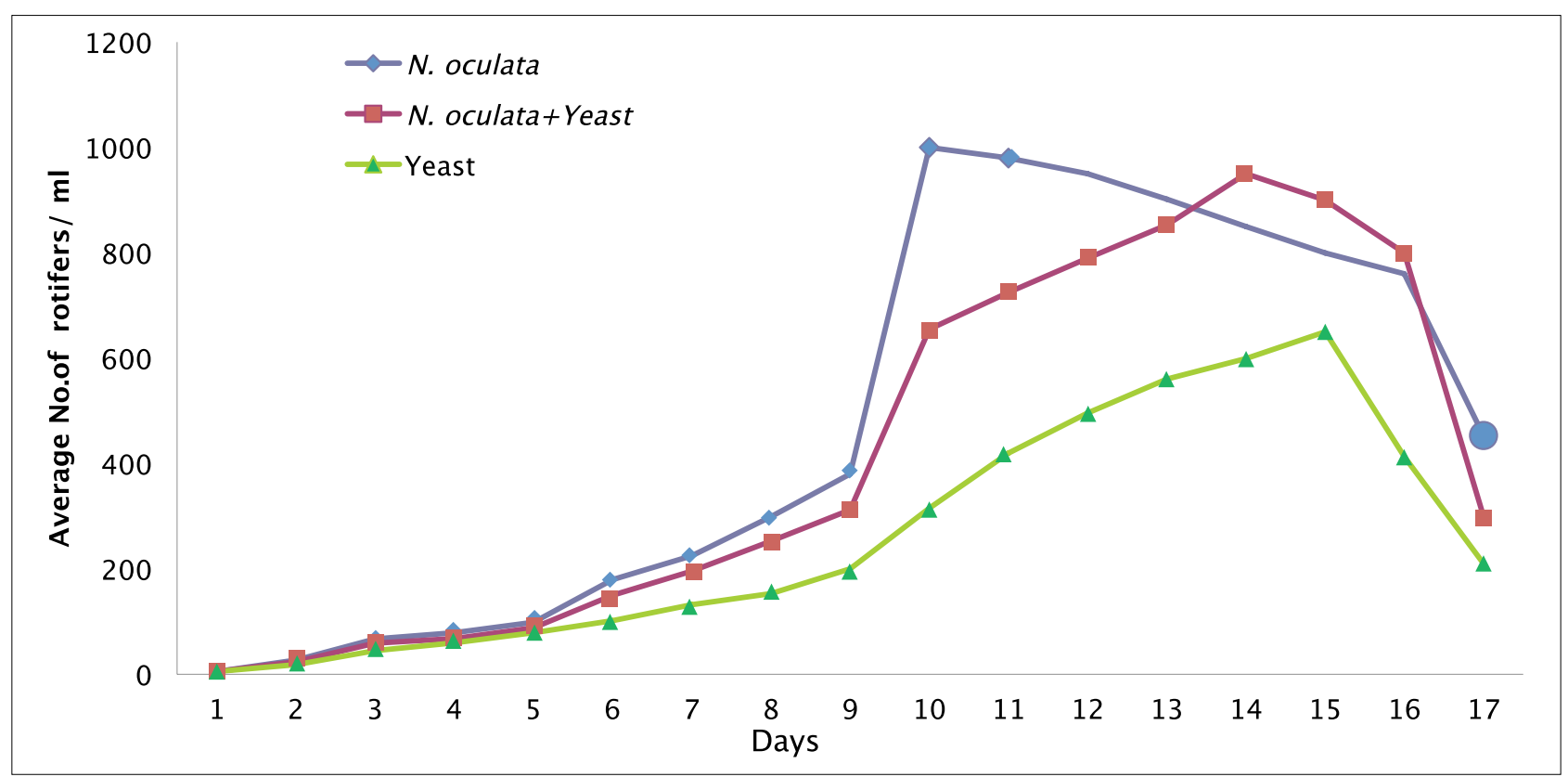

Fig. 6. Population density of C. adriatica fed with different feed at 34 ppt salinity

Table 2. Survival in larvae of marine ornamental species fed with C. adriatica as first feed up to 10 day of post hatch (dph)

\begin{tabular}{lll}
\hline Species & $\begin{array}{l}\text { Larval survival (\%) upto } 10 \text { dph fed with C. } \\
\text { adriatica }\end{array}$ & $\begin{array}{l}\text { Larval survival (\%) upto 10 dph fed with } \\
\text { B. rotundiformis }\end{array}$ \\
\hline Pomacentrus caeruleus & 80 & 20 \\
\hline Stenopus hispidus & 60 & 10 \\
\hline Lysmata amboinensis & 45 & 5 \\
\hline
\end{tabular}

Preliminary studies of $C$. adriatica as a feed to the larvae

Preliminary studies on feeding the larvae of marine ornamental banded coral shrimp S. hispidus, scarlet cleaner shrimp L. amboinensis and blue Caerulean damselfish $P$. caeruleus with $C$. adriatica showed that the larvae had ingested it. The survival obtained in larvae fed with $C$. adriatica and $B$. rotundiformis up to 10 days of post hatch are presented in Table 2 and revealed that the larval survival is significantly higher $(p<0.05)$ when fed with $C$. adriatica than $B$. rotundiformis. Thus the study revealed that $C$. adriatica can be used as first feed in larval rearing of high value fin and shell fishes before weaning them to larger sized live feed organism. The newly hatched larvae are of two types precocial and altricial. Precocial larvae are those which appear as mini adults, exhibits fully developed fins and mature digestive system with functional stomach and also can able to ingest and digest formulated diets. However, in altricial larvae, when the yolk reserve is exhausted, they remain relatively in an undeveloped state with rudimentary digestive system and lacks stomach (Stottrup and Mc Evoy, 2003). In such case the protein digestion is being taken place in the hind gut epithelial cells (Govoni et al., 1982), hence unable to accept formulated feeds. Therefore, altricial larvae require suitable sized live feeds. Most of the marine fishes have altricial type larvae and hence need to be fed with suitable sized live feed organism as first feed. Recent report also revealed that use of $C$. adriatica in grouper larval rearing was successful (Wullur et al., 2013). Hence the isolation and culture of $C$. adriatica which is smaller than $B$. rotundiformis (SS type) is a major breakthrough in larval rearing of marine fishes.

\section{Acknowledgements}

The authors wish to express their sincere thanks to the Director, CMFRI for all the support and facilities provided. Thanks are also due to Dr. Christian D. Jersabek, Academy of Natural Sciences of Drexel University in Philadelphia, USA \& Department of Organismic Biology, Centre for Systematic Biology and Evolution, University of Salzburg, Austria for the help rendered in confirming the species identification, and to Dr. Sandhya Sukumaran, CMFRI for DNA sequences. The authors are also thankful to Mr. Abhilash, P. R., Mr. David, K. M, Artist and all the staff of Marine Hatchery of CMFRI for their valuable support. 


\section{References}

Arora, J. and N. K. Mehra. 2003. Species diversity of planktonic and epiphytic rotifers in the backwaters of the Delhi segment of the Yamuna River, with remarks on new records from India. Zool. Stud., 42: 239-247.

Baribwegure, D. and H. Segers. 2001. Rotifera from Burundi:the Lepadellidae (Rotifera: Monogononta). Hydrobiologia, 446/447: 247 -254.

De Ridder, M. and $H$ Segers. 1997. Monogonont Rotifera recorded in the world literature (except Africa) from 1960 to 1992.Studie doc. K.B.I.N. 88: 481.

De Smet, W. H. 1994. Lepadella beyensi (Rotifera Monogononta: Colurellidae), a new species from the Canadian high arctic. Hydrobiologia, 294:61-63.

De Smet, W. H. 2006. Some Marine Rotifera from Reunion Island, with a Description of a New Species of Lindia Harring and Myers, 1924 and one of Synchaeta Ehrenberg, 1832, Zool. Stud., 45(1): 81-92.

Dhert, P. 1996. Rotifers In: P. Lavens and P. Sorgeloos (Eds.) Manual on the Production and Use of Live Food for Aquaculture, FAO Fisheries Technical Paper, 361, p.49-78.

Folmer O., M. Black, W. Hoeh, R. Lutz and R. Vrijenhoek. 1994. DNA primers for amplification of mitochondrial cytochrome $c$ oxidase subunit I from diverse metazoan invertebrates Mol. Mar. Biol. Biotechnol., 3(5):294-9.

Govoni, J. J., D. S. Peters and J. V. Merriner. 1982. Carbon assimilation during larval development of the marine teleosts Leiostomus xanthurus Lacepede. J. Exp. Mar. Biol. Ecol., 16:287-299.

Hagiwara, A., T. Kotani, T. W. Snell, M. Assava-Aree, and K. Hirayama.1995. Morphology, reproduction and genetics of the tropical minute marine rotifer Brachionus strains. J. Exp. Mar. Biol. Ecol., 194: 25-37.

Hauer, J. 1924. Zur Kenntnis des Rotatorien-Genus Colurella, Bory de st. Vincent. Zool. Anz., 59: 177-186.

Holt, G. J. 2003. Research on culturing the early life history stages of marine ornamental species. In: J.C.Cato, C.L. Brown (Eds.) Marine Ornamental Species: Collection, Culture and Conservation. lowa State Press, p. 251- 254.

Houde, E. D. and R. C. Schekter.1980. Feeding by marine fish larvae: developmental and functional responses. Env. Biol. Fish., 5:315-334.

Hunter, J. R. 1981. Feeding ecology and predation of marine fish larvae. In: R. Lasker (Ed.) Marine fish larvae. Univ. of Washington Press, Seattle. p. 33-77.

Jersabek C. D. and M. F. Leitne. 2013 . The rotifer World Catalog. World Wide Web electronic publication. http://rotifera.hausdernatur.at/Species/Index/365, accessed on 29th April 2016.

Knuckey, R. M., I. Rumengan and S. Wullur. 2004. SS-strain Rotifer Culture for Finfish Larvae with Small Mouth Gape. In: M.A. Rimmer, S. McBribe and K.C. Williams (Eds) Advances in Grouper Aquaculture. ACIAR Monograph Series. p. 21-25.
Leszek A. B. and A. M. Ellison. 2003. Diversity of rotifers from northeastern US Abogs with new species records for North America and New England. Hydrobiologia, 497:53-62.

Lim, L. C. 1993. Larviculture of the greasy grouper Epinephelus tauvina and the brownmarbled grouper E. fuscoguttatus in Singapore. J. World Aquac. Soc., 24: 262274.

Molly Varghese, 2003. The rotifer Brachionus rotudiformis Tschungunoff isolated from Cochin backwater, Kerala. J. Mar. Biol. Ass. India, 45 (1) : 108-110.

Pejler, B. 1962. Taxonomic notes on some planktonic freshwater rotifers. Zool. Bidr: Uppsala, Bd. 35: 307-319.

Rimper, J., R. Kaswadji, B. Widigdo, N. Sugiri, Inneke and F. M. Rumengan. 2008. Body size of rotifers (Brachionus rotundiformis) from estuaries in North Sulawesi. Aquaculture Asia Magazine, January-March : 49-50.

Sharma, B. K. and S. Sharma. 2015. The diversity and distribution of Lepadellidae (Rotifera: Eurotatoria: Monogononta) of India. International Review of Hydrobiology, 100:34-42.

Snell, T. W. and K. Carrillo, 1984. Body size variation among strains of the rotifer Brachionus plicatilis, Aquaculture, 37(4): 359-367.

Somamihardja, A. and A. Bart. 2008. Characterization of Small-size Egg-bearing Thai ss-strain Rotifers Brachionus rotundiformis and Their First Offspring J. World Aquac. Soc., 39(4): 528-534.

Sorenson, M. V. and R. M. Kristensen. 2000. Marine Rotifera form Ikka Fjord, SW Greenland: With a description of a new species from the rare mineral ikaite, In: Meddelelser om Groenland, Bioscience, Vol. 51, Compenhagen, the Danish Polar Center, pp. 1-46.

Stottrup, J. G. and L. A. McEvoy. 2003. Live Feeds in Marine Aquaculture, Blackwell Science Ltd, lowa, USA, pp.1-313.

Tocher, D. R., G. Mourente and J. R. Sargent.1997. The use of silages prepared from fish neural tissue as enrichers for rotifers (Brachionus plicatilis) and Artemia in the nutrition of larval marine fish. Aquaculture,148:213-231.

Turingan, R.G., J. L. Beck. J. M. Krebs and J. D. Licamele. 2005. Development of feeding mechanics in marine fish larvae and the swimming behaviour of zooplankton prey: implications for rearing marine fishes. In: C.S. Lee, P.J. Bryen, N.H. Marcus (Eds.) Copepods in Aquaculture. Blackwell Publishing, Ames, Iowa, USA, pp. 234-248.

Wullur, S., H. B. Lahope and I. F. M. Rumengan, H. Pangkey, J. R. T. S. L. Rimper and E. Kaligis. 2013. Colurella sp.cf. adriatica (Rotifera:Ploimida) a new promising live food for larval rearing of marine tropical fish. In: Seminar Tahunan ke-2 dan Workshop Bioteknologi Kelautan Perikanan. Manado, 16-18 September 2013, Abstract . p.53. 